\title{
KEMADIRIAN PAKAN BERBASIS HIJAUAN LOKAL UNTUK KERBAU DI PROVINSI BANTEN
}

\author{
Prihantoro I, Aryanto AT, Karti PDMH \\ Depertemen IImu Nutrisi dan Teknologi Pakan, Fakultas Peternakan, Institut Pertanian Bogor. \\ email: iprihantoro@yahoo.com
}

\begin{abstract}
ABSTRAK
Hijauan merupakan pakan utama ternak kerbau di peternakan rakyat. Kebutuhan hijauan pakan akan meningkat seiring tuntutan peningkatan populasi kerbau. Kerbau dipelihara secara semi intensif di padang penggembalaan alam, pekarangan dan terintegrasi dengan lahan pertanian. Ketersediaan hijauan untuk kerbau rendah pada musim kemarau. Tujuan penelitian adalah mengukur potensi hijauan pakan dan strateginya untuk kemandirian pakan hijauan bagi kerbau di Provinsi Banten. Penelitian dilaksanakan di padang penggembalaan kerbau (padang alam dan terintegrasi pertanian) yang dikelola oleh peternak rakyat di Kabupaten Lebak dan Serang Provinsi Banten. Parameter yang diukur meliputi: (1) komposisi botani hijauan pakan, (2) kapasitas tampung hijauan pakan, (3) jenis-jenis tanaman pakan di padang penggembalaan kerbau, (4) kualitas produk silase dan hay dari hijauan pakan asal padang penggembalaan kerbau. Hasil penelitian menunjukkan bahwa komposisi botani yang bervariasi dengan dominasi vegerasi utama adalah jenis rumput (56,55-95,94\%), nilai kapasitas tampung rendah dan bervariasi ( $0.29 \pm 0.17-0.98 \pm 0.39$ UT/ha). Diperoleh 24 jenis tanaman pakan yang berpotensi sebagai hijauan pakan bagi kerbau. Dihasilkan produk hijauan hasil penyimpanan berupa silase dan hay yang berpotensi sebagai sumber pakan pada musim kemarau.
\end{abstract}

Kata kunci : kemandirian pakan, kerbau, padang penggembalaan, peternakan rakyat

\begin{abstract}
Forage is the main feed of buffalo in smallholder farms. The need of forage will increase along to the increased demand of buffalo population. Buffaloes are kept as semi-intensive in natural grassland, house yard and integrated with agricultural land. Forages availability for buffalos are low in the dry season. The aim of this research is to measure the potential forage and the strategy for self-sufficiency of forage for buffalo in Province of Banten. The research was conducted in buffalo pasture (natural and integrated with paddy fields) managed by smallholder farmers in Lebak and Serang Regencies, Banten Province. Parameters measured include: (1) botanical composition of forage, (2) forage carrying capacity, (3) types of feed crops in buffalo pastures, (4) quality of silage and hay products from buffalo pasture. The results showed that botanical composition was varied with predominant vegetation dominance was grasses (56.55-95.94\%), low and varied carrying capacity (0.29 $\pm 0.17-0.98 \pm 0.39 \mathrm{AU} / \mathrm{ha}), 24$ types of forage plant were found which are potential as buffalo feed. Silage and hay from buffalo grassland were potential as feed resources in the dry season.
\end{abstract}

Keywords: buffalo, natural grassland, self-sufficient feed, smallholder

\section{PENDAHULUAN}

Hijauan makanan ternak merupakan sumber pakan utama bagi ternak ruminansia, khususnya kerbau pada peternakan skala rakyat. Tuntutan peningkatan populasi ternak ruminansia, seiring peningkatan komoditas produk asal ternak ruminansia, akan berkorelasi langsung pada peningkatan kebutuhan pakan ternak, di antaranya adalah pakan asal hijauan. Hingga saat ini, peternakan ruminansia di Indonesia berbasis pada peternakan rakyat dengan skala kepemilikan yang rendah (berkisar 1-4 ST/
KK) dan sangat tergantung pada pakan hijauan yang berasal dari alam (pekarangan dan padang rumput alam). Ketersediaan pakan hijauan relatif fluktuatif, berkualitas rendah dan sangat ditentukan oleh musim, ketersediaannya senantiasa terbatas/kekurangan pada saat musim kemarau.

Kemandirian pakan hijauan yang berkualitas dan berkelanjutan merupakan salah satu kunci keberhasilan usaha peternakan ruminansia. Upaya penyediaan hijauan pakan secara berkesinambungan terkendala atas beberapa faktor, yakni faktor lingkungan dan terbatasnya alokasi lahan khusus untuk memproduksi 
pakan hijauan. Upaya memaksimumkan produktivitas hijauan pakan di antaranya melalui pendekatan potensi keragaman hijauan yang tumbuh pada kawasankawasan yang selama ini dimanfaatkan sebagai sumber pakan ternak, baik dalam pemeliharaan yang intensif, semi intensif maupun ekstensif.

Pola pemeliharaan ternak kerbau di Provinsi Banten terdominasi dengan pola pemeliharaan ekstensif dan semi intensif, dimana ternak kerbau ditempatkan di sekitar padang penggembalaan sepanjang waktu dengan cara diikat menggunakan tali tambang dengan ukuran yang bervariasi (4-15 m). Secara periodik berdasarkan kelompok-kelompok ternak, kerbau digeser pada tempat-tempat yang ditumbuhi hijauan sebagai pakan utamanya.

Managemen pemeliharaan padang penggembalaan alam oleh peternak skala rakyat, umumnya relatif sederhana dan cenderung tanpa managemen khusus. Sepenuhnya hijauan pakan yang dimanfaatkan adalah pakan hijauan yang tumbuh alami dan belum dilakukan managemen khusus seperti : perawatan, pemupukan maupun introduksi HMT unggul teradaptasi lingkungan domestik yang cenderung basah. Parakkasi (1999) menyatakan bahwa di Indonesia dan daerah tropis lainnya belum diperoleh keterangan secara pasti tentang adanya suatu hijauan yang menonjol kualitasnya. Hal ini bisa disebabkan masih kurangnya eksplorasi dan identifikasi sumberdaya genetik (plasma nutfah) hijauan ada. Padahal untuk mengembangkan peternakan yang mempunyai daya saing diperlukan pemanfaatan sumberdaya lokal yang mempunyai nilai lebih. Salah satunya adalah pemanfaatan hijauan yang mempunyai kualitas nutrisi yang baik dan telah beradaptasi dengan kondisi iklim setempat.

Hingga saat ini, kajian tentang sebaran jenis hijauan pakan teradaptasi lingkungan basah dengan peruntukan bagi ternak kerbau di provinsi Banten dan pemanfaatannya sebagai produk tersimpan berupa silase dan hay masih relatif terbatas. Tujuan penelitian adalah mengukur potensi hijauan pakan dan strateginya untuk kemandirian pakan hijauan bagi kerbau di Provinsi Banten.

\section{MATERI DAN METODE}

Materi yang digunakan meliputi kuadran ukuran $50 \times 50 \mathrm{~cm}$, tali, timbangan digital, kantong plastik,spryer, alkohol 70\%, spidol permanent, label, sabit, koran, pisau, parang dan ember. Bahan yang digunakan meliputi molases, hijauan pakan alam yang tumbuh di padang penggembalaan alam dan terintegrasi dengan pertanian.

Metode Penelitian meliputi beberapa kegiatan : (1) Pengukuran komposisi botani tanaman pakan dengan metode "Dry Weight Rank" menurut Mannetje dan Haydock (1963) melalui penaksiran komposisi botani lahan tanpa melakukan pemotongan dan pemisahan spesies. Secara acak ditetapkan 50 titik pengamatan menggunakan kuadran ukuran 50 $x 50 \mathrm{~cm}$. Selanjutnya dilakukan pencatatan jenis spesies tanaman berdasarkan estimasi peringkat spesies, (2) Pengukuran kapasitas tampung lahan menurut Hall et al. (1964). Secara acak ditetapkan 5 titik lokasi sebagai sampel menggunakan kuadran ukuran 50 x $50 \mathrm{~cm}$. Selanjutnya sampel tanaman dipotong, untuk memperoleh bobot kering tanaman menggunakan oven $60{ }^{\circ} \mathrm{C}$, (3) Identifikasi hijauan pakan dengan teknik herbarium menurut Bean (2013). Sampel tumbuhan lengkap meliputi batang, daun dan bunga di potong dan disterilisasi menggunakan alkohol $70 \%$. Selanjutnya ditempel secara sistematis pada kertas dan ditetapkan identitas nama lokal dan lokasi sampel. Herbarium selanjutnya dianalisis untuk ditetapkan nama latin tanaman berdasarkan referensi, (4) Pembuatan silase menggunakan ember plastik kapasitas $12 \mathrm{~kg}$. Sebanyak 3 sampel HMT dari masing-masing titik lokasi dimasukkan ke dalam ember dengan cara ditekan/diinjak hingga penuh. Parameter yang diukur meliputi warna, aroma dan kontaminan, (5) Pembuatan hay hijauan pakan alam. Hay dibuat dengan sampel sebanyak $10 \mathrm{~kg}$ dengan cara dikeringkan dengan menggunakan panas matahari hingga kering udara. Parameter yang diukur meliputi tingkat kekeringan dan warna.

\section{HASIL DAN PEMBAHASAN}

Tingkat produktivitas ternak ditentukan oleh beberapa faktor, di antaranya adalah jenis ternak, kualitas genetik dan managemen budidaya. Pakan merupakan salah satu komponen penting dalam managemen budidaya ternak. Kerbau merupakan ternak semi aquatik yang mampu berdaptasi tinggi pada pakan berkualitas rendah dengan tingkat kecernaan 2-3 kali lebih tinggi di banding sapi (Wanapat et al, 1994). Tingginya ketergantungan peternakan kerbau skala rakyat terhadap pakan alam, menuntut pengelolaan lahan lebih baik sehingga ketersediaan hijauan terjamin dan berkelanjutan sepanjang tahun. Hal-hal yang perlu diperhatikan untuk menjaga dan meningkatkan produktivitas lahan dan ternak adalah kemampuan lahan dalam penyediaan hijauan pakan untuk mencegah terjadinya over grazing dan under grazing.

\section{Komposisi Botani Padang Penggembalaan Kerbau}

Komposisi botani merupakan suatu metode yang digunakan untuk menggambarkan adanya spesies- 
spesies tumbuhan tertentu serta proporsinya di dalam suatu ekosistem padangan. (Susetyo, 1980) menyatakan bahwa komposisi suatu padangan cenderung tidak konstan, hal ini disebabkan karena adanya perubahan susunan akibat adanya pengaruh iklim, kondisi tanah dan juga pemanfaatannya oleh ternak.

Spesies hijauan yang tumbuh di padang penggembalaan alam dan terintegrasi sawah cukup bervariasi. Nilai Komposisi Botani hijauan pakan yang tumbuh di area penggembalaan kerbau disajikan pada Tabel 1.

Tabel 1. Komposisi Botani Hijauan Pakan di Area Penggembalaan Kerbau

\begin{tabular}{lccccc}
\hline \multirow{2}{*}{ Vegetasi } & \multicolumn{5}{c}{ Lokasi } \\
\cline { 2 - 6 } & \multicolumn{1}{c}{ I } & III & IV & V \\
\cline { 2 - 6 } & 64,26 & 56,55 & 85,96 & 88,12 & 95,94 \\
Rumput & 0 & 0 & 2,70 & 11,66 & 3,56 \\
Legum & 35,74 & 43,46 & 11,34 & 0,22 & 0,50 \\
Gulma/rumbah & &
\end{tabular}

Keterangan : lokasi I, II adalah lahan terintegrasi pertanian padi dan lokasi III, IV, V adalah lahan padang penggembalaan alam

Hasil penelitian menunjukkan bahwa nilai komposisi botani padang penggembalaan dari setiap titik yang diukur menunjukkan nilai yang bervariasi. Kecenderungan dari lokasi penelitian menunjukkan bahwa nilai dominasi vegetasi rumput pada lokasi I dan II lebih sedikit dibandingkan rataan vegetasi rumput pada lokasi III, IV dan V. Kondisi ini menunjukkan bahwa area terintegrasi lahan pertanian padi memungkinkan munculnya vegetasi selain rumput yang dapat dikategorikan sebagai gulma/ rumbah. Meskipun demikian, rataan nilai komposisi botani dari tanaman pakan jenis leguminosa untuk semua lokasi relatif tebatas yakni pada kisaran (o11\%). Hasil ini menunjukkan bahwa kualitas area penggembalaan kerbau berdasarkan komposisi hijauan yang tumbuh relatif rendah. Idealnya nilai komposisi untuk managemen polikultur dari ketiga jenis berturut adalah Rumput : Legum : Gulma = $60: 40: 0$.

Pemanfaatan pakan hijauan yang hanya mengandalkan jenis rumput alam belum mampu memenuhi kebutuhan nutrien ternak, ternak yang sedang dalam periode pertumbuhan akan memperlihatkan tingkat pertambahan bobot badan yang rendah. Ketersediaan dan kualitas nutrien rumput alam juga akan makin menurun saat musim kering dan hal ini akan berpengaruh langsung terhadap produktivitas ternak (ACIAR 2008). Keberadaan hijauan pakan jenis leguminosa akan meningkatkan asupan protein bagi ternak. Leguminosa juga dapat membantu fiksasi nitrogen dalam tanah sehingga proses pertumbuhan rumput dipadang pengembalaan dapat bertumbuh baik. Padang penggembalan ini merupakan daerah yang tidak menentu kondisinya, yakni pada saat musim hujan maka hijauan akan tergenang air dan pada saat musim kemarau akan sangat kekeringan.

\section{Kapasitas Tampung Padang Penggembalaan Kerbau}

Kajian kapasitas tampung adalah suatu cara untuk mengevaluasi padang penggembalaan dengan mengetahui jumlah ternak yang dapat ditampung dalam suatu areal pastura dengan menjaga kelestarian lahan, tanaman dan ternak itu sendiri. Analisis kapasitas tampung menggambarkan kemampuan areal padang penggembalaan atau kebun rumput untuk dapat menampung sejumlah ternak, sehingga kebutuhan hijauan rumput dalam 1 tahun sebagai makanan ternak tersedia dengan cukup. Kapasitas tampung padang penggembalaan atau kebun rumput, erat berhubungan dengan jenis ternak, produktivitas hijauan, musim, dan luas padang penggembalaan atau kebun rumput. Oleh karena itu, kapasitas tampung relatif bervariasi antar lokasi.

Tabel 2. Kapasitas Tampung Hijauan Pakan di Area Penggembalaan Kerbau

\begin{tabular}{|c|c|c|c|c|c|}
\hline & \multicolumn{5}{|c|}{ Lokasi } \\
\hline & 1 & II & III & IV & $\mathrm{V}$ \\
\hline & \multicolumn{5}{|c|}{...... (UT/Ha) ...... } \\
\hline $\begin{array}{l}\text { Kapasitas } \\
\text { Tampung }\end{array}$ & $0.78 \pm 0.42$ & $0.29 \pm 0.17$ & $0.31 \pm 0.16$ & $0.98 \pm 0.39$ & $0.82 \pm 0.47$ \\
\hline
\end{tabular}

Hasil kajian menunjukkan bahwa status kapasitas tampung dari padang penggembalaan kerbau di wilayah Serang relatif bervariasi dan pada kisaran yang relatif rendah, yakni dengan rataan kapasitas tampung lahan berkisar $0.29 \pm 0.17-0.98 \pm 0.39$ UT/Ha. Padang penggembalaan yang baik, idealnya mampu menampung ternak hingga 2 UT/Ha.

Rendahnya nilai kapasitas tampung pada lokasi kajian di antaranya disebabkan oleh : 1 . belum dilakukan managemen budidaya hijauan melalui input pupuk pakan dengan baik, 2. Belum dilakukan pengembangan jenis lokal unggul dan introduksi jenis hijauan pakan unggul yang tinggi nutrisi dengan produktivitas yang tinggi, dan 3. Belum dilakukan pola rotasi yang baik dan benar sehingga status padang penggembalaan cenderung over grazing. Ruswendi (2004) menyatakan bahwa ketersediaan hijauan pakan dipengaruhi oleh iklim dan pola pertanian tanaman pangan, pada musim hijauan tanaman hijauan tumbuh dengan baik dan tersedia dalam jumlah banyak. 


\section{Jenis Hijauan Pakan Teradaptasi di Area Penggembalaan Kerbau}

Maksimalisasi jenis hijauan unggul yang telah terdomestikasi pada lahan padang penggembalaan menjadikan pemanfaatan dan pengembangan hijauan tersebut akan lebih optimal dibandingkan melalui introduksi jenis baru yang belum tentu mampu berkembang dan beradaptasi baik pada lingkungan spesifik lokasi pengembangan. Hasil penelitian didapatkan beberapa jenis hijauan yang tumbuh di lokasi penelitian, sebagaimana disajikan pada Tabel 3 .

Beberapa jenis hijauan yang ditemukan di areal padang penggembalaan kerbau meliputi beberapa jenis, yakni kelompok Graminae, Leguminosae, rumbah dan tanaman pangan. Di antara hijauan yang tumbuh merupakan jenis hijauan unggul yang memungkinkan untuk dikembangkan lebih maksimal, seperti jenis Brachiaria humidicola, Brachiaria mutica, Leucaena leucocephala. Meskipun demikian, masih menuntut jenis lain yang idealnya dikembangkan di padang penggembalaan seperti Brachiaria decumben dan Stylosanthes $s p$ yang memiliki adaptabilitas tinggi dan tahan dengan injakan ternak serta jenis rumput potongan dengan pruduktivitas yang tinggi seperti Pennisetum purpureum. Selain itu menuntut pengembangan jenis hijauan yang memiliki ketahanan tinggi terhadap kekeringan, seperti jenis leguminosa pohon Indigofera $s p$.

Tabel 3. Jenis Hijauan yang Tumbuh di Area Penggembalaan Kerbau

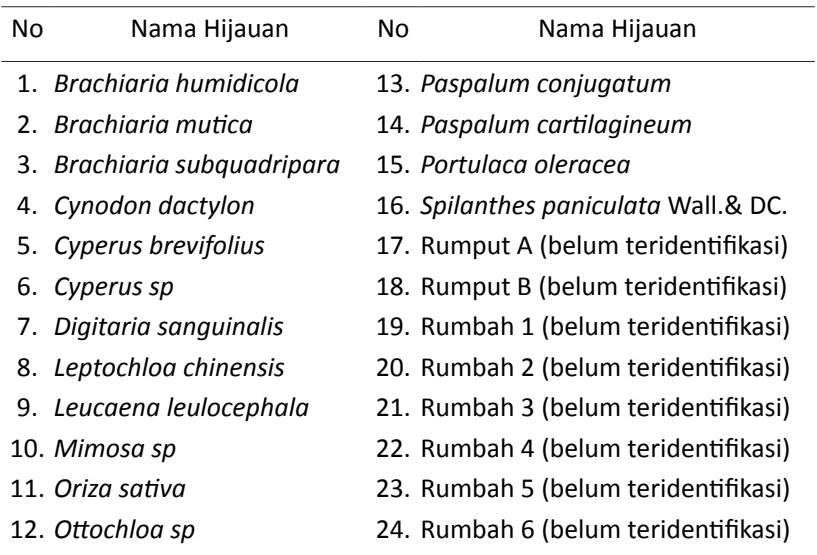

\section{Kualitas Hay dan Silase asal Hijauan Padang Penggembalaan Kerbau}

Silase yang baik beraroma harum seperti bau tape, tidak terdapat jamur, berwarna coklat kekuningan, tektur utuh seperti segar (Syarifuddin, 2006). Silase yang terbuat dari hijauan yang berasal dari area penggembalaan kerbau memiliki warna cenderung hijau kecoklatan, dengan aroma sedikit asam. Detail kualitas silase hijauan area penggembalaan kerbau disajikan pada Tabel 4 .

Secara umum, produk silase beraroma sedikit asam dengan warna silase hijau kecoklatan
Tabel 4 Kualitas Silase Asal Hijauan di Area Penggembalaan Kerbau

\begin{tabular}{|c|c|c|c|}
\hline Lokasi & Warna & Jamur & Aroma \\
\hline 1 & hijau kecoklatan & + & sedikit asam \\
\hline II & $\begin{array}{l}\text { hijau kecoklatan } \\
\text { Produk silase yang dihasilkan } \\
\text { cenderung bau }\end{array}$ & + & sedikit asam \\
\hline III & hijau kecoklatan & + & sedikit asam \\
\hline IV & Kecoklatan & ++ & sedikit asam \\
\hline V & hijau kecoklatan & + & sedikit asam \\
\hline
\end{tabular}

hingga coklat. Munculnya jamur pada bagian atas produk adalah wajar yang dimungkinkan akibat ketidakmaksimalan proses dalam menciptakan kondisi media yang an aerob. Pendekatan pembuatan silase yang telah dilakukan adalah murni sampel hijauan tanpa penambahan bahan sumber gula sederhana. Pendekatan ini dilakukan untuk mempermudah peternak ketika melaksanakan penyimpanan pakan berbasis silase.

Kualitas silase yang baik dicapai ketika asam laktat sebagai asam yang dominan diproduksi, menunjukkan fermentasi asam yang efisien dan penurunan $\mathrm{pH}$ terjadi secara cepat. Semakin cepat fermentasi yang terjadi maka semakin banyak nutrisi yang dikandung silase dapat dipertahankan (Schroeder, 2004). Disamping itu faktor yang mempengaruhi kualitas silase secara umum juga dipaparkan yaitu kematangan bahan dan kadar air, besar partikel bahan, penyimpanan pada saat ensilase dan aditif. Kualitas silase juga dipengaruhi oleh 1) karakteristik bahan (kandungan bahan kering, kapasitas buffer, struktur fisik dan varietas), 2) tata laksana pembuatan silase (besar partikel, kecepatan pengisian ke silo, kepadatan pengepakan, dan penyegelan silo), 3) keadaan iklim (suhu dan kelembaban) (Sapienza dan Bolsen, 1993).

Pendekatan penyimpanan selanjutnya adalah penyimpanan kering melalui pembuatan produk hay. Hasil penelitian produk hay asal bahan hijauan yang diambil dari area penggembalaan kerbau disajikan pada Tabel 5 .

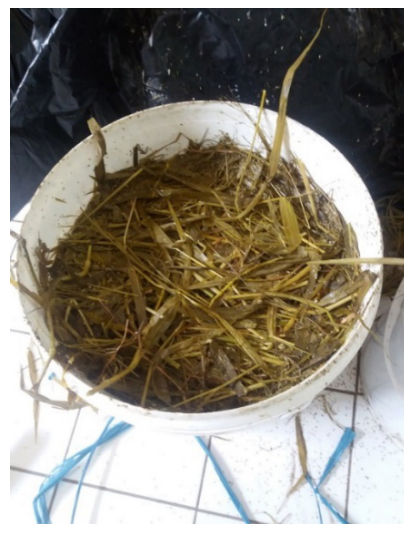

(a)

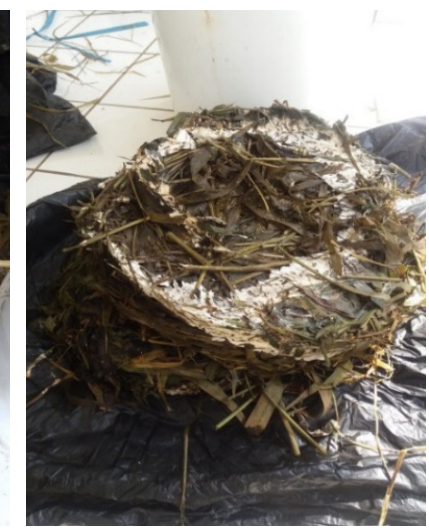

(b)
Gambar 1. Kondisi Silase Asal Hijauan di Area Penggembalaan Kerbau. (a) adalah 3/4 Bagian Bawah Silase dan (B) adalah Bagian 1/3 Bagian Atas Silase. 
Tabel 5 Kualitas hay asal hijauan di area penggembalaan kerbau

\begin{tabular}{ccc}
\hline Lokasi & Bahan Kering (\%) & Warna \\
\hline I & 34,05 & Kuning kecoklatan \\
II & 34,25 & Kuning kecoklatan \\
III & 34,32 & Kuning kecoklatan \\
IV & 33,12 & Kuning kecoklatan \\
V & 34,55 & Kuning kecoklatan \\
\hline
\end{tabular}

Kualitas hay yang diperoleh pada penelitian ini relatif kurang maksimal, karena bahan baku hijauan yang diperoleh memiliki kadar air yang tinggi, sekitar 33.12-34.55\%, sedangkan kualitas hay yang bagus memiliki kadar air sebesar $12-20 \%$, kandungan air yang tinggi ini diakibatkan proses pengeringan dan penyimpanan yang kurang maksimal, bahan hay diangin-anginkan tanpa ada pengeringan yang layak dengan pengeringan oven. Pendekatan penyimpanan berbentuk hay dimaksudkan agar hijauan saat disimpan sebagai hay tidak ditumbuhi jamur. Jamur akan merusak kualitas hijauan yang diawet menjadi hay. Adapun tujuan pembuatan hay adalah untuk penyediaan hijauan untuk pakan ternak pada saat kritis dan pada saat ternak diangkut untuk jarak jauh.

\section{SIMPULAN}

Nilai komposisi botani dari area penggembalaan kerbau bervariasi dengan dominasi vegerasi utama adalah jenis rumput (56,55 - 95,94\%), nilai kapasitas tampung rendah dan bervariasi (0.29 \pm 0.17

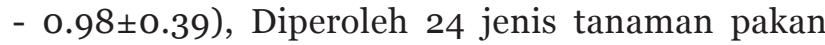
yang potensial sebagai hijauan pakan bagi kerbau, Dihasilkan produk hijauan hasil penyimpanan berupa silase dan hay yang berpotensi sebagai sumber pakan pada musim kemarau.

\section{DAFTAR PUSTAKA}

ACIAR. 2008. Strategies to Increase Growth of Weaned Bali Cattle. Final Report. Project number LPS 2004023.

Bean T. 2013. Collecting and Preserving Plant Specimens, a Manual. Queensland (AU): The State of Queensland, Department of Science, Information Technology and Innovation.

Hall L.K., R. H. Hughs, L. Runmel, B. L. Southwel. 1964. Forage and Cattle Management in Longleaf Slaash Pine Forest. Bul Farmer's : 2199

Mannetje, L. \& K. P. Haydock. 1963. The dry weight rank method for the botanical analysis of pasture. J. British Grassland Society. Vol. 18.

Parakkasi A. 1999. Ilmu Nutrisi dan Makanan Ternak Ruminansia. Universitas Indonesia Press, Jakarta.

Ruswendi. 2004. Analisis potensi sumberdaya pakan ternak untuk pabrik pakan ternak sapi potong di Kabupaten Gunungkidul. Tesis. S2 Program Pascasarjana Universitas GadjahMada. Yogyakarta

Sapienza D. A dan K. K. Bolsen. 1993. Teknologi Silase. Penerjemah: Martoyoedo RBS. PionerHi-Bred International, Inc. Kansas State University.

Schroeder J. W. 2004. Silage fermentation and preservation. Extension Dairy Specialist. AS1254. www.ext.nodak.edu/extpubs/ansci/ dairy/ as1254w.htm. [June 2004]

Susetyo S. 1980. Pengelolaan dan Potensi Hijauan Makanan Terak untuk Produksi Ternak Daging. Fakultas Peternakan. Institut Pertanian Bogor.

Syarifuddin N. A. 2006.Karakteristik dan Persentase Keberhasilan Silase Rumput Gajah pada Berbagai Umur Pemotongan. Fakultas Peternakan Universitas Lambung Mangkurat Banjarbaru. Banjarmasin.

Wanapat M., K. Sommart, C. Wachirapakorn, S. Uriyapongson, C. Wattanachant. 1994. Recent advance in swamp buffalo nutrition and feeding. Proc. The $1^{\text {st }}$ Asian buffalo Association Congress. Khon Kaen University, January 17-21. 1994. 